\title{
RTEL1 wt Allele
}

National Cancer Institute

\section{Source}

National Cancer Institute. RTEL1 wt Allele. NCI Thesaurus. Code C134633.

Human RTEL1 wild-type allele is located in the vicinity of 20q13.33 and is approximately $38 \mathrm{~kb}$ in length. This allele, which encodes regulator of telomere elong ation helicase 1 protein, is involved in telomere and chromosome maintenance. Mutation of the gene is associated with telomere-related pulmonary fibrosis and/or bone marrow failure 3 and dyskeratosis congenita types autosomal dominant 4 and autosomal recessive 5 . 